\title{
П.Р.ТРЕТЯК ${ }^{1}$, Ю.І. ЧЕРНЕВИЙ
}

\section{ОСОБЛИВОСТІ ЛІСОВОЇ ТИПОЛОГІЇ В КРАЇНАХ} АЛЬПІЙСЬКО-КАРПАТСЬКОГО МАКРОРЕГІОНУ

У загальноєвропейському масштабі тип лісу розуміють як категорію, визначену за складом деревної рослинності та умовами місця росту. Основою лісотипологічної класифікації лісової рослинності у гірських країнах Європейського Союзу є природничо-лісова регіоналізація та рангування типів лісу за висотними ступенями рослинності у горах. Подальша диференціація лісового континууму пов'язується з особливостями геологічного підгрунтя, рівнями родючості грунтів, ступенями зволоженості та діапазонами ї̈ мінливості. Кожен тип лісу у межах конкретного регіону позначається формулою, що містить послідовний ряд абревіатур наведених категорій, який завершується шифром клімаксового лісового рослинного угруповання. Досягнення лісівничих шкіл сусідніх гірських країн у побудові схем системноструктурної диференціації лісового покриву та класифікацій типів лісу можуть слугувати прототипами, за якими варто було б здійснити комплексне удосконалення лісової типологї Українських Карпат.

Ключові слова: Альпи, Карпати, ліси, структура, типи, регіоналізація, наукові школи, геологічне підгрунтя, геотопи, трофотопи, гігротопи

Вступ. Структурі лісового покриву у багатомірному просторі географічного середовища біосфери властивими $є$ риси континуальності i дискретності. Вони проявляються у зонально-географічній, висотно-поясній та локальній едафотопічній диференціації. Водночас, лісу, як системі живих організмів, що залежить від умов зовнішнього середовища, властивою $є$ здатність саморозвиватися і впливати на формування свого середовища. Окрім цього, особливо значний, формувальний і перетворювальний вплив на лісовий покрив справляє господарська діяльність. Однак дотеперішня практика виділення типів лісу в Україні, яка досить добре зарекомендувала себе у

\footnotetext{
${ }^{1}$ ТРЕТЯК Платон Романович - дійсний член Лісівничої академії наук України, віце-президент ЛАН України, доктор біологічних наук, професор, Державний природознавчий музей НАН України, м. Львів, Україна. Тел.: +38-067-662-68-41. E-mail: platon.tretyak@gmail.com

2 ЧЕРНЕВИЙ Юрій Іванович - член-кореспондент Лісівничої академії наук України, кандидат сільськогосподарських наук, Прикарпатський лісогосподарський коледж, м. Болехів, Україна. Тел.: +38-034-37346-68. E-mail: plhc@ukr.net
} 
рівнинних умовах, у горах виявилася недостатньою. Тому до найбільш проблематичних у лісовій типології Українських Карпат належать питання структуризації гетерогенності корінного лісового покриву, зокрема його локальних структур, залежно від специфічних висотно-кліматичних та ґрунтово-гідрологічних умов. Без їх належного вирішення важко встановити характер клімаксових деревостанів у конкретних клімато-грунтово-гідрологічних умовах, а отже, й локальні типи лісу, які відповідали б критеріям динамічно пов’язаних серій похідних деревостанів 3 корінними. Саме тому протягом останніх 50 років періодичне лісовпорядкування в Карпатах змушене було постійно удосконалювати номенклатуру та структуру типів лісу [1, 20]. Це особливо відчутно позначилося на типології мішаних гірських лісів за участю кількох едифікаторних видів, що призвело до певної відмінності у трактуванні структури корінного лісового покриву регіону, зокрема у його геоботанічному та лісівничому районуванні [4-10].

Найбільш повно досліджував типологічну структуру лісів Українських Карпат 3.Ю. Герушинський [2, 3]. Він виділив 78 типів лісу за різним складом деревної рослинності, що є характерними для лісорослинних умов Карпат. Очевидно, що це мали б бути клімаксові лісові угруповання. Однак питання їх діагностики на локальному рівні досі так і залишилися невирішеними. До речі, лісовпорядкування продовж останніх десятиліть значно розширили так звану номенклатуру типів лісу Карпат. Під типом лісу практики все-таки розуміють не ті абстрактні збірні типологічні одиниці, які мали на увазі класики лісової типології, а відміни типів деревостанів старшого віку у певних кліматоедафотопічних умовах.

Значного поступу у дослідженні гетерогенності структури типів лісу добилися вчені сусідніх країн Альпійсько-Карпатського макрогегіону. Їх досягнення заслуговують уваги та адаптації при удосконаленні лісової типології Українських Карпат. Тому метою цієї публікації є представлення широкому загалу українських науковців узагальнення цього доробку, який міг би посприяти подальшому розвитку лісової типології Українських Карпат. 
Європейська стратегія лісової політики. Головною метою лісової політики і практики в європейських країнах є стале управління лісами (SFM) щодо використання їх та лісових земель у напрямку підтримання потенційних можливостей біорізноманіття, продуктивності, життєздатності та регенерації. Тому конференція на рівні міністрів зі захисту лісів в Європі (MCPFE) започаткувала становлення лісової політики високого рівня щодо загальних розмірів сталого лісокористування (SFM) у європейському регіоні. До складу MCPFЕ увійшли 44 країни Європейського континенту (в тому числі Україна та Росія). Збереження біорізноманіття лісів вважають невід’ємною частиною SFM MCPFE [13].

Відповідно до концепції MCPFE, тип лісу розуміють загалом як «категорію лісу, визначену за його складом та (або) умовами місця росту, таким чином, щоб відповідні системи категорій кожної країни підходили для такого розуміння» [13]. Таке концептуальне бачення забезпечує гнучкий підхід до збору та систематизації інформації про стан лісового господарства у кожному регіоні. Відповідно до звітності МСРFЕ (переклад якої подаємо далі за оригіналом) «... класифікація типів лісів повинна визначити і відобразити головні природні й антропогенні чинники диференціації стану лісів і які здатні викликати значні зміни у показниках станів базових типів лісу...». Зазначений вище підхід до розуміння типів лісу дає змогу порівнювати їх стан у всій Європі у подібних екологічних умовах. При цьому до уваги беруть пан-європейські критерії та показники для збалансованого управління лісами (SFM), що включають базові характеристики типів лісу. Насамперед, це ті, що визначають підтримання i відповідно зростання обсягів лісових ресурсів та їх внесок у глобальному кругообігу вуглецю. Це площа лісів, їх запас, вікова структура деревостанів та (або) розподіл їх за товщиною стовбурів. Також оцінюють санітарний стан та життєздатність лісових екосистем, їх ураженість пошкодженнями. Значну увагу надають підтриманню, збереженню та покращанню біологічної різноманітності у лісових екосистемах. Оцінюють загальну площу лісів та інших лісистих місцевостей за видовим складом, за їх природністю (незмінені людиною, 
напівприродні та плантаційні), а також наявний обсяг стоячого та лежачого сухостою [13].

3 такого підходу враховують ключові чинники, які мають великий вплив на (або) безпосередньо відображають зміну біорізноманіття в європейських лісах. Ключові фактори класифікують відповідно до різних компонентів лісових екосистем, до яких належать структурні (фізичні) характеристики, композиційні (біотичні компоненти, тобто види дерев); функціональні фактори (абіотичні та біотичні) обмежувальні і спрямовувальні.

Структурними ключовими характеристиками $є$ загальна площа лісів залежно від їх правового статусу, використання або захисних функцій, власності на ліси, розподілу за деревними породами та віком, наявністю старовікових та відновлених лісів природного походження, заліснених та знеліснених територій. Серед композиційних чинників розрізняють природні автохтонні деревні види та інтродуковані й нетипові місцеві види. Функціональні чинники - це такі, як порушення рослинного покриву природними процесами: пожежами, вітром i снігом, біотою, діяльністю людей, лісогосподарськими та агрокультурними заходами та випасом худоби, а також забрудненням та іншими формами землекористування [13].

Запропоновані підходи та критерії забезпечують можливість застосування широкого і структурованого опису різноманітності європейських лісів на основі GLC2000 (Global Land Cover Database) зональності. Зокрема, для помірних широт Європи виділяють зони листопадних шпилькових лісів, листопадних широколистяних лісів, широколистяно-шпилькових лісів, шпильково-широколистяних лісів, мішаних лісів тощо [13].

Класифікаційна система типів лісу Європи враховує їх сучасний стан і оцінення можливого потенціального розвитку. Досі існували дві протилежні схеми систематики та ідентифікації екологічного виокремлення лісових угруповань всієї Європи. Це природнича інформаційна система Євросоюзу (EUNIS) і класифікація просторових ділянок (habitat - оселище, середовище перебування), а також перелік фітосоціологічних об’єднань рослинних 
угруповань Європи. Незважаючи на популярність цих підходів та їх широке застосування, вони виявилися недостатніми для уніфікації потреб моніторингу типів лісу континенту [13].

По-перше, обидві системи мають нереальну для застосування у звітності МСРFE кількість класів. Зокрема, система EUNIS вже на другому рівні класифікації визначає чотири класи лісових місцезростань, які $€$ неінформативними. На третьому і четвертому рівнях узагальнення вона $\epsilon$ функціонально непридатною, оскільки містить відповідно 52 і більше 700 різних типів просторових ділянок. Ці лісові місцезростання відповідають 110 союзам рослинних угруповань фітосоціологічного переліку. Союзи не чіткі і не охоплюють штучні ліси, тобто плантаційні [13].

По-друге, типи лісових рослинних угруповань, що перераховані у фітосоціологічному переліку, визначені на основі методичного підходу, який не $є$ доступним для спільноти кінцевих користувачів MCPFE [13].

По-третє, найважливіше обмеження: сумнівна ефективність застосування цих класифікацій у задоволенні потреб звітності МСРFЕ. Для того, щоб бути корисною для оцінення стану лісів МСРFЕ, лісова типологія повинна відображати, наскільки це можливо, реальні зміни у характері лісової екосистеми у загальноєвропейському масштабі. Наприклад, це екологічні зміни в лісових зонах, які впливають на видовий склад природних деревостанів, тривалість вегетаційного сезону, що впливає на їх запаси, швидкість перебудови та природного відпаду (всихання: тип і кількість); зміни режимів господарювання, які контролюють вік і структуру щільності деревостану, а також наявність залишків омертвілої деревини у лісі [13].

Європейську класифікаційну схему типів лісу побудовано на основі всеосяжного огляду пропозицій 25 країн ЄС, запропонованих для оптимізації масштабного моніторингу стану біологічного різноманіття лісів. Цю розробку виконала група вчених [11]. Вона грунтується на існуючих традиціях виділення типів лісу для оцінення біорізноманіття в Європі. Ця схема передбачає 14 
категорій та 78 типів європейських лісів. Зокрема, серед них стосуються карпатського регіону такі:

4. Кислі дубові та дубово-березові ліси (4.1. Кислі дубові; 4.2. Дубовоберезові).

5. Мезофітні листопадні ліси (5.1. Дуба звичайного та граба; 5.2 Дуба скельного та граба; 5.3. Ясеневі і дубово-ясеневі; 5.4. Кленово-дубові тощо).

6. Букові ліси (6.5. Карпатські передгірські букові ліси).

7. Гірські букові ліси (7.5. Карпатські гірські букові ліси; 7.9. Гірські ялинові ліси).

13. Незаплавні вільхові, березові або осикові ліси.

14. Плантації з дерев інтродукованих видів.

Така класифікація є, напевно, цілком задовільною у загальноєвропейському вимірі, проте, на наш погляд, примітивною у регіональному, зокрема стосовно Карпатської гірської країни. Напевно, що вона не є придатною для використання у лісогосподарській практиці багатьох гірських країн Європи. Саме тому вони застосовують національні лісотипологічні класифікації, що враховують регіональні екологічні та флористичні особливості лісового покриву. Ці питання досить добре висвітлено у працях багатьох дослідників лісотипологічних шкіл Австрії, Німеччини, Чехії, Словаччини, Польщі [12-23].

Альпійсько-карпатська природничо-лісова регіоналізація та висотна диференціація. Головні принципи лісівничого планування у більшості держав враховують насамперед природні умови: особливості геологічної будови і клімату, зміни клімату і локальні умови місць росту. На цих засадах формують природничо-лісову регіоналізацію. Геологічний та кліматичний чинники розглядають у взаємозв’язку, який зумовлює існування великих геологогеоморфологічних структур. Такими, зокрема, є Альпійська та Карпатська гірські країни, Швейцарське і Баварське передгірні плато, Передкарпатські височини, Тисо-Дунайська низовина тощо. Це не лише оригінальні орографічні утворення, але й морфоструктури рельєфу, що впливають не лише на формування макроклімату на європейському континенті, а і його регіональних, 
висотно-поясних та експозиційних відмін. Своєю чергою, особливості геологічної будови та форм рельєфу визначають характер та інтенсивність екзогенних геофізичних та геохімічних процесів, що формують специфічне підгрунтя поверхневих гірських порід, які відрізняються за ступенем фізичного, хімічного та біологічного вивітрювання, фізичними та хімічними властивостями. Водночас особливості рельєфу, кліматичні умови та склад гірських порід визначають процеси фізичного та хімічного вимивання гірських порід, а також характер водно-геохімічного режиму та ступінь забезпечення вологою грунтів, водного переносу та нагромадження змитих субстанцій, а також напрямки окисно-відновних процесів. Це i $€$ основа формування локальних лісорослинних умов. Зміни клімату, що відбулися у віддаленій ретроспективі та впродовж кількох останніх століть визначили напрямки міграції флористичних елементів, формування складу рослинних угруповань та тенденції їх подальшого природного розміщення в географічному просторі.

На цих засадах побудовано схеми природно-лісової регіоналізації. Наприклад, в Австрії виділяють такі природничо-лісові райони: Альпи, Альпійське передгір’я, Віденський ліс, Позаальпійські області без теплих низовин, Теплі низовини [23, с. 10]. У Словаччині є такі природничі регіони: Паннонська рівнинна низовина (західна та східна частини), західні Карпати (Словенсько-Моравські, Західні Бескиди, Східні Бескиди, Підгально-Магурська область, Фатрансько-Татранська область, Словенське середньогіря, ЛуженьскоКошіцьке пониження тощо), Східні Карпати (низькі Бескиди, Полонини, Вигорлат-Гутинська область). У південно-східній Польщі це так звана Карпатська країна, яку поділено на 9 природничо-лісових районів. Зокрема, це Середньобескидське Погурже (височина та низькогір’я), Бещади, Підгалля (охоплює височину та низькогір’я, що прилягає до Татр).

Окрім природно-лісових регіонів, подальшу диференціацію лісової рослинності розглядають на основі висотно-кліматичної поясності. 
В Австрії прийнято розглядати диференціації лісового рослинного покриву за ступенями висоти над рівнем моря ("Höhenstufe-Seehöhe (m)"). Виділяють вісім таких висотних поясів рослинності [23, с. 9]:

1. "Kollin" (до 300 м н.р.м.) - передгір’я Альп і низовини, де ростуть теплолюбні, переважно дубові, ліси на алювіальних грунтах.

2. "Submontan" (300-700 м н.р.м.): 2-a - низькі горбисті височини i глибокі долини в горах, де ростуть багаті мішані дубові ліси з грабом; 2-б алювіальні височини передгір'я - підніжжя гір, де ростуть букові ліси з дубом (в Альпах з дубом, сосною та ялицею).

3. "Tiefmontan" (700-900 м н.р.м.) - низькогір'я, де ростуть ялиновоялицево-смереково-букові ліси, букові ліси (в Альпах бука немає).

4. "Mittelmontan" (900-1200 м н.р.м.) - середньовисокі гори, де ростуть ялицево-смереково-букові ліси (в Альпах бука немає).

5. "Hochmontan" (1200-1400 м н.р.м) - високі гірські масиви, де ростуть ялицево-смереково-букові ліси та ялицево-смерекові ліси (в Альпах бука немає).

6. "Tiefsubalpin" (1400-1800 м н.р.м) - низький субальпійський пояс перехідний до високогір'я, де до висоти 1600 м н.р.м. ростуть ялицевосмерекові ліси, а вище - смерекові ліси.

7. "Subalpin" (1800-2200 м н.р.м) — субальпійський рівень, перехідний до альпійського, де ростуть модриново-кедрові, модринові і соснові ліси.

8. "Alpin" (вище 2200 м н.р.м) - альпійський пояс, де поширені чагарникові стелюхи, луки, кам'янисті розсипи, трапляються фрагменти деревної рослинності.

У Чехії та Словаччині лісівники користуються категоріями висотних рослинних ступенів А. Златніка [24], а саме: 0 - Pinus sylvestris (соснових лісів); 1 - Quercus (дубових лісів); 2 - Fagus-Quercus (буково-дубових лісів); 3 Quercus-Fagus (дубово-букових лісів); 4 - Fagus (букових лісів); 5 - Abies-Fagus (ялицево-букових лісів); 6 - Picea-Fagus (ялиново-букових лісів); 7 - FagusPicea (буково-ялинових лісів); 8 - Picea (ялинових лісів); 9 - Pinus mugo (субальпійського криволісся сосни гірської). 
У Польщі застосовують простішу схему [18]. Тут оперують категоріями висотних географічних поверхів, виділяючи такі: передгірні височини; нижній гірський (бучини); верхній гірський (ялинові бори); субальпійський (стелюхи сосни гірської); альпійський (високогірні луки, полонини); субнівальний, скелястий.

Класифікація локальних лісорослинних умов. Локальну диференціацію лісового рослинного покриву у всіх лісотипологічних школах згаданих країн розглядають на основі місцевих особливостей лісорослинних умов [22]. Подібно як і в Україні, до уваги беруть, головним чином, показники трофності та гідрологічного режиму.

У лісовому господарстві Австрії для кожного природничо-лісового регіону при класифікації типів лісорослинних умов [23] враховують, насамперед, особливості геологічного підгрунтя, а саме: КА - на карбонатних породах (вапняки, доломіти), Sl - на силікатних породах (гнейси, граніти, Schiefer), FL - на флішових відкладах (мергелі та пісковики). Трофність класифікують за п'ятьма рівнями родючості грунтів, що забезпечують енергію росту деревної рослинності (дуже бідні, бідні, середньої родючості, родючі і дуже багаті). При цьому враховують потужність грунтів (дуже плиткі, плиткі, середні, глибокі і дуже глибокі). Гідрологічні умови класифікують як дуже сухі, помірно сухі, частково сухі, сухі, помірно свіжі, свіжі, дуже свіжі, вологі насичені вологою, заболочені. У підсумку оцінюють придатність ділянок для вирощування лісу, а також умови та доцільність господарювання, заготівлю деревини, біомаси тощо (низька, середня, висока).

У лісівництві Баварії (Німечина) застосовують подібну як в Україні координаційну систему трофічних і гідрологічних типів геотопів (табл.). 
Координаційна таблиця едафотопів (лісорослинних умов), яку застосовують у лісівництві Баварії [19, с. 16 ]

\begin{tabular}{|c|c|c|c|c|c|c|c|}
\hline \multicolumn{3}{|c|}{$\begin{array}{c}\text { Feuchtestufe } \\
\text { Ступені зволоження }\end{array}$} & \multicolumn{5}{|c|}{$\begin{array}{l}\text { Trophisch und hygrisch bestimmte Geotoptypen } \\
\text { Трофічні і гідрологічні відміни типів геотопів }\end{array}$} \\
\hline \multirow{3}{*}{ III } & 7 & $\begin{array}{l}\text { Aquatisch - } \\
\text { водойми }\end{array}$ & A7 & G7 & M7 & K7 & R7 \\
\hline & 6 & $\mathrm{Naß} \mathrm{-} \mathrm{болота}$ & A6 & G6 & M6 & K6 & R6 \\
\hline & 5 & $\begin{array}{l}\text { Grundfeucht - } \\
\text { вологі грунти }\end{array}$ & A5 & G5 & M5 & K5 & R5 \\
\hline \multirow{3}{*}{ II } & 4 & Frisch - свіжі & A4 & G4 & M4 & K4 & $\mathrm{R} 4$ \\
\hline & 3 & $\begin{array}{c}\text { mäßig frisch - } \\
\text { майже свіжі }\end{array}$ & A3 & G3 & M3 & K3 & R3 \\
\hline & 2 & $\begin{array}{l}\text { mäßig trocken - } \\
\text { майже сухі }\end{array}$ & A2 & G2 & M2 & K2 & $\mathrm{R} 2$ \\
\hline I & 1 & Trocken - cyxi & $\mathrm{Al}$ & Gl & $\mathrm{Ml}$ & $\mathrm{Kl}$ & $\mathrm{RI}$ \\
\hline \multicolumn{3}{|c|}{$\begin{array}{c}\text { Gesmtnährkraftstufe } \\
\text { ступені потенціалу родючості }\end{array}$} & $\begin{array}{c}\text { A } \\
\text { arm } \\
\text { бідні }\end{array}$ & $\begin{array}{c}\mathrm{G} \\
\text { gering } \\
\text { трохи } \\
\text { багатші }\end{array}$ & $\begin{array}{c}\text { M } \\
\text { mittel } \\
\text { середні }\end{array}$ & $\begin{array}{c}\mathrm{K}- \\
\text { kräftig } \\
\text { досить } \\
\text { багаті }\end{array}$ & $\begin{array}{c}\mathrm{R} \\
\text { reich } \\
\text { багаті }\end{array}$ \\
\hline
\end{tabular}

Класифікацію типів лісу Польщі також формують на основі подібної до української координаційної сітки едафотопів [12, 16, 18, 22]. Ряд трофотопів такий: В - бори, ВМ - мішані бори, LM - мішані ліси, L - ліси. Бори ототожнюють з бідними підзолистими піщаними або каменистими грунтами; мішані бори - з кислими опідзоленими буроземами та сірими супіщаними грунтами; мішані ліси - з більш багатими кислими буроземами, а листяні ліси з багатими справжніми буроземами та чорноземами. На рівнинах застосовують гідрогенний ряд, що містить такі типи гігротопів: s - cyxi, sw - свіжі, w - вологі, b - болотні, $ł$ - заплавні. На височинах і в горах гідрогенний ряд замінено висотними поясами клімату та рослинності: WG - високогірний, G - гірський нижній, $\mathrm{G} \mathrm{-} \mathrm{заплавний} \mathrm{гірський,} \mathrm{Wyż} \mathrm{-} \mathrm{височинний.} \mathrm{Відповідно} \mathrm{до} \mathrm{названих}$ типів лісорослинних умов вказують характерні корінні лісові угруповання.

Подібними $є$ й засади геобіоценологічної диференціації та класифікації лісів А. Златніка, що застосовують у Словаччині [15, с. 71-166]. В основу екологічної сітки типів лісу покладено попередньо згаданий вертикальний ряд висотних ступенів рослинності. Для кожного висотного поясу подають едафічно-гідротопічну сітку. Горизонтально розташований ряд геобіоценів, що 
містить такі едафічно-трофічні категорії та міжкатегорії: А - оліготрофні, А/В геміоліготрофні, В - мезотроні, В/C - гемінітрофільні, С - нітрофільні, D кальцієфільні. Окремо подають заплавні типи едафотопів, які називають "субори". Вирізняють субори ацидофільні - "а" і субори нітрофльні - "с". Вертикальний ряд містить такі категорії гігротопів:

1. Обмежене зволоження, достатнє тільки для низької рослинності;

2. Частково обмежене зволоження, достатнє для рослинності: 2а - на плитких грунтах; 2b - на пісках.

3. Нормальне зволоження, достатнє для рослинності головних трофотопів: За - у різних рослинних поясах; 3b - у посушливо-дощовому кліматі Чехії та Моравії; Зс - у посушливо-дощовому кліматі Карпатських котловин Словаччини.

4. Заболочені типи.

5. Мокрі типи: 5a - із проточною водою; 5b - зі стоячою водою.

Відповідно до висотних ступенів рослинності та типів трофотопів подають властиві їм типи потенційних природних лісових фітоценозів. У клітинах такої екологічної сітки розміщено абревіатури типів лісу. Наприклад: "02. Quercetum, Q. - dúbrava":

Lesné typy (типи лісу):

1111 Dúbrava obmedzeného vzrastu, callunagenpildešf, (O - низькоросла діброва верескова);

1112 Dúbrava normálneho vzrastu,dešfgenpil, (Н - діброва нормального росту);

1113 Dúbrava s bukom, lncythirs, (H - діброва з буком);

1114 Kostravová dúbrava na pieskoch, focarsup, (H - кострицева діброва на пісках);

1115 Kostravovo-lipnicová produkč. dúbrava na pieskoch (H - кострицеволипова діброва на пісках).

Складнішою є чеська класифікація лісових екосистем [21]. Це так звана «Екологічна сітка типологічної системи місць росту лісових комплексів», яку 
розробив Інститут управління лісами Чеської республіки. По вертикалі у такій сітці лісові природні комплекси диференційовано за серією едафотопів без врахування значення грунтового зволоження, а саме:

1. EXTREMUM (екстремальні на силікатних каменистих розсипах ):

$\mathrm{X}$ - xerothermica (ксеротермічні); Z - humilis (низькі); $\mathrm{Y}$ - saxatilis (кам'янисті).

2. ACIDOPHILUM (кислі):

M - oligotrophica (бідні); K - acidophila (кислі); I - illimerosa acidophila (помірно кислі); $\mathrm{N}$ - lapidosa acidophila (кам'янисті кислі).

3. TROPHICUM (багаті, родючі):

S - mesotrophica (середньої родючості); C - subxerothermica (субксеротермічні); F - lapidosa mesotrophica (камянисті, середньої родючості); Н - illimerosa trophica (помірно родючі); В - trophica (багаті, родючі); W - calcaria (вапнисті).

4. ACEROSA (пухкі кам'янисті відклади):

D - deluvia (делювіальний); A - acerosa lapidosa( мішані з камінням); J saxatilis acerosa (кам'янисті мішані з опадом).

5. FRAXINOSA (ясеневі):

L - alluvialis (алювіальні); U - vallidosa (важкі); V - huтіda (вологий).

6. VARIOHUMIDA (оглеені)

O - variohumida mesotrophica (оглеені середньої родючості); P variohumida acidophila (оглеєні кислі); Q - variohumida oligotrophica (оглеєні бідні).

7. PALUDOSA (заболочені):

T - paludosa oligotrophica (заболочені бідні); G - paludosa (торф'яні).

Усі ці категорії едафотопів розглядають диференційовано, насамперед за висотними ступенями рослинного покриву, які в екологічний таблиці цієї типологічної системи розташовані у вигляді горизонтального ряду.

Групи типів геобіоценів подають для кожної клітини «едафотоп / висотна ступінь» у порядку зростання зволоження. Ряд умов зволоження 
містить такі категорії: 1 - сухі; 2 - обмежені; 3 - нормальні; 4 - заболочені, сирі; 5 - мокрі: a - проточні, b - застійні; 6 - торфові.

Однак їх застосовують до певних типів лісу у вигляді таких категорій інтервалів значень зволоження, наприклад:

обмежене слабке: 1, 1-2, 2, 2 (3); нормальне: 2-3, (2) 3, 3, 3 (4); заболочене: 3-4, (3) 4, 4, 4-5, 4 (5), 4 (6); мокре проточне: (4) 5, 5а; мокре застійне: 5б; торф (4) 6, 6.

Групи типів геобіоценів пов’язані з відповідними типами локальних екологічних умов, які виявляють за допомогою біоіндикації рослинних угруповань. У групи цих типів геобіоцени асоційовані на основі фітосоціологічної подібності біоти природних лісів на стадії стиглості. Групи типів геобіоценів приурочені до певних однорідних екологічних умов (кліматичних, гідрологічних і трофічних), які зумовлюють їх особливу загальну просторову структуру i склад біоти, продуктивність i динаміку розвитку. Отже, маючи можливість оптимально використовувати адекватні природні умови, певні типи геобіоценів повинні мати конкретний функціональний потенціал [22, с. 28].

Групи типів геобіоценів, за певних умов навколишнього середовища i пов'язаного 3 ними потенціалу біоти, позначають геобіоценологічними формулами. Насамперед вказують вертикальний пояс рослинності, далі категорію (міжкатегорію) трофності, потім - гігротопічні умови, у вигляді геобіоценологічного діапазону відповідних категорій. Наприклад, геобіоценологічна формула «ЗВЗ» позначає групу типу геобіоценів Quercifageta typica (типова дубова бучина) у «3» висотному поясі дубових лісів, мезотрофної групи В і в нормальному гідрологічному режимі «З». Скорочено такий тип геобіоцену позначають «QFt».

Висновки. Наведені особливості концептуальних основ природнолісової регіоналізації та висотно-кліматичної поясності, які розроблено у різних країнах альпійсько-карпатського макрорегіону, загалом близькі до тих підходів, які застосовують в Україні. Однак розроблені для Українських Карпатах геоботанічне, геоботанічно-лісівниче та комплексне лісогосподарське 
районування [3, с. 100-109] потребують узгодження 3 макрорегіональними моделями та осучаснення. Відповідно до потреб ведення Державного лісового кадастру потрібно на урядовому рівні прийняти остаточну схему природничолісового районування. Відповідно до конкретних районів потрібно розробити схеми вертикальної кліматичної поясності лісів відповідної структури та продуктивності.

Значні досягнення вчених-лісівників сусідніх гірських країн у пошуку системно-структурних особливостей лісового покриву на локальному рівні можуть бути прототипом, за яким належить здійснити системно-структурне удосконалення класифікації типів лісу Українських Карпат. Насамперед, заслуговують уваги принципи виділення трофотопів за ступенем сформованості та кислотності грунтів, а також діапазонів умов зволоження на локальному рівні. Це особливо актуальні проблемні питання в умовах схилового рельєфу гір. Відповідно, такі координаційні схеми специфічних едафотопічних умов потрібно було б розробити для всіх висотно-кліматичних поясів 3 поданням відповідних показників продуктивності деревостанів за відповідними едифікаторними видами.

Лісову типологію Українських Карпат доцільно доопрацювати, запозичивши дослід лісівничих шкіл сусідніх держав. Насамперед варто остаточно удосконалити лісівниче районування, наблизивши його до відповідних категорій природничо-лісової регіоналізації Західних Карпат. Типи лісорослинних умов потрібно, передусім, пов'язати 3 висотними поясами лісової рослинності і деталізувати відповідно до особливостей геологічного підгрунтя і стану сформованості грунтів.

\section{СПИСОК ВИКОРИСТАНИХ ДЖЕРЕЛ}


1. Бойчук I.I. Тенденції змін складу деревостанів у найпоширеніших типах лісу в середньогір’ї Горган / Ігор Бойчук // Лісівнича академія наук України: Наукові праці. - 2003. - Вип. 2. - С. 75-78.

2. Герушинский 3.Ю. Определитель типов леса Украинских Карпат : практические рекомендации / Герушинский 3.Ю. - Львов, 1988. - 164 с.

3. Герушинский 3.Ю. Типологія лісів Українських Карпат : навч. посіб. [для студ. вищ. навч. закл.] / Герушинский 3.Ю. - Львів: Піраміда, 1996. - 208 с.

4. Генсірук С.А. Ліси України : моногр. / Генсірук С.А. - К.: Наук. думка, 1992.- 408 с.

5. Генсірук С.А. Ліси Українських Карпат та їх використання : моногр. / Генсірук С.А. - К.: Урожай, 1964. - 291 с.

6. Голубец М.А. Ельники Украинских Карпат : моногр. / Голубец М.А. К.: Наук. думка, 1978. - 254 с.

7. Голубець М. Геоботанічне районування Українських Карпат основа раціонального природокористування / М. Голубець // Праці Наукового товариства ім. Шевченка. Екологічний збірник: Екологічні проблеми Карпатського регіону. - 2003. - Т. 12. - С. 283-292.

8. Молотков П.И. Буковые леса Карпат и хозяйство в них : моногр. / Молотков П.И. - М.: Лесн. пром-сть, 1966. - 244 с.

9. Сабан Я.А. Экология горных лесов : моногр. / Сабан Я.А. - М.: Лесн. пром-сть, 1982. - 168 с.

10. Украинские Карпаты. Природа : моногр. / [Голубец М.А., Гаврусевич А.Н., Загайкевич И.К. и др.]; под. ред. М.А. Голубца. - К.: Наук. думка, 1988. - 208 с.

11. Barbati A. New European Forest Types. Complementary documentation. Annex to Enquiry. State of Forests and Sustainable Forest Management in Europe 2011 / A. Barbati, P. Corona, M. Marchetti. - United Nations, Geneva February 2010. $-9 \mathrm{p}$. 
12. Chodzicki E. Lasy ziem Polski a warunki przyrodnicze / E. Chodzicki // Dzieje lasów, leśnictwa i drzewnictwa w Polsce. - Warszawa: Państwowe wydawnictwo rolnicze i leśne, 1965. - S. 18-32.

13. European forest types. Categories and types for sustainable forest management reporting and policy. - Luxembourg: Office for Official Publications of the European Communities, 2006. - 111 p.

14. Hofmann G. Mitteleuropäische Wald- und Forstökosystemtypen in Wort und Bild / G. Hofmann. - AFZ/Der Wald: Sonderheft, 1997. - 85 s.

15. Krizova E. Fytocenologia a lesnicka typologia / E. Krizova. - Vydala Technická univerzita vo Zvolene v Edičnom stredisku. - 1995. - 182 s.

16. Murat E. Hodowla lasu. Podręcznik dla techników leśnych. Cz. IV. / E. Murat. - Warszawa: Wydawnictwo Świat, 1998. - 182 s.

17. Obmiński Z. Regionalizacja przyrodniczo-leśna. Cz. IV / Z. Obmiński // Dzieje lasów, leśnictwa i drzewnictwa w Polsce. - Warszawa: Państwowe wydawnictwo rolnicze i leśne, 1965. - S. 32-39.

18. Siedliskowe podstawy hodowli lasu. Załącznik nr 1 do Zasad hodowli i użytkowania lasu wielofunkcyjnego. - Warszawa, 2003. - 280 s.

19. Thomasius H. Wald- und Forstökosysteme auf Kippen des Braunkohlenbergbaus in Sachsen - ihre Entstehung, Dynamik und Bewirtschaftung / H Thomasius, M. Wünsche, H. Selent, A. Bräunig // Schriftenreihe der Sächsische Landesanstalt für Forsten. - Heft 17/1999. - 72 s.

20. Tretiak P. Zmiany w składzie gatunkowym lasów w Gorganach / Platon Tretiak // Roczniki Bieszczadzkie. - Tom. 7. - 1998. - S. 327-334.

21. Viewegh J. Czech forest ecosystem classification / J. Viewegh, A. Kusbach, M. Mikeska // Journal of Forest Science. - 49. - 2003 (2). - 74-82 s.

22. Viewegh J. Klasifikace lesních rostlinných společenstev (se zaměřením na Typologický systém ÚHÚL) / Jiří Viewegh - Česká zemědělská univerzita v Praze. Katedra dendrologie a šlechtění lesních dřevin, 2003. - 203 s.

23. Weinfürter P. Waldbau in Österreich auf ökologischer Grundlage. Eine Orientierungshilfe für die Praxis / P. Weinfürter. - Wien: PEFC, 2013. - 248 p. 
24. Zlatnik A. Lesnická fitocenologia / Alois Zlatnik. - Praha: Státni zemédélski nakladetelstwi, 1978. - 495 s.

\section{П.Р. Третяк, Ю.И. Черневый}

\section{ОСОБЕННОСТИ ЛЕСНОЙ ТИПОЛОГИИ В СТРАНАХ АЛЬПИЙСКО-КАРПАТСКОГО МАКРОРЕГИОНА}

В многомерном пространстве географической среды биосферы современному лесному покрову присущи черты континуальности и дискретности. Эти обстоятельства затрудняют построение моделей типов леса.

Главной целью лесной политики и практики в европейских странах является устойчивое управление лесами (SFM) по использованию лесов и лесных земель в направлении поддержания потенциала их биоразнообразия, продуктивности, жизнеспособности и регенерации. В целом тип леса принято понимать как категорию, определенную по его составу и (или) условиям места роста таким образом, чтобы соответствующие системы категорий каждой страны подходили для такого понимания, а классификация типов лесов могла бы определить и отразить главные природные и антропогенные факторы дифференциации состояния лесов, которые способны вызывать значительные изменения в показателях состояний базовых типов леса.

В большинстве стран главные принципы лесоводческого планирования учитывают, прежде всего, природные условия: особенности геологического строения и климата, изменения климата и локальные условия мест роста. На этих принципах построена естественная лесная регионализация. Геологический и климатический факторы рассматривают во взаимосвязи, которая обуславливает существование крупных геолого-геоморфологических структур. В то же время особенности рельефа, климатические условия и состав горных пород определяют характер водно-геохимического режима, степень обеспечения влагой, процессы физического и химического вымывания горных 
пород и почв, водного переноса и накопления смытых субстанций, а также направления окислительно-восстановительных процессов. Это основа формирования локальных лесорастительных условий. В основу экологической сетки типов леса обычно положен вертикальный ряд высотных ступеней растительности. Для каждого высотного пояса предлагается соответствующая эдафо-гидротопическая координационная сетка, которая содержит ряд категорий трофотопов, а также ряд категорий условий увлажнения.

Этих категорий может быть разное количество и им предоставляется разный смысл, что отражает не только градацию плодородия почв, но и их мощность, кислотность, обеспеченность нитратами. Ряд гигротопов может содержать от 4 до 7 категорий (подкатегорий) степеней увлажнения или обеспечения влагой, а также интервалов увлажнения.

Согласно высотных ступеней растительности и типов трофотопов указываются присущие им типы потенциальных природных лесных фитоценозов. В клетках такой экологической сети размещены аббревиатуры типов леса, а также названия ассоциаций растительных группировок.

Ключевые слова: Альпы, Карпаты, леса, структура, типы, регионализация, научные школы, геологический субстрат, геотопы, трофотопы, гигротопы 


\section{P. Tretyak, Yu. Chernevyy}

\section{FEATURES OF FOREST TYPOLOGY, THAT IS IN THE COUNTRIES OF ALPINE-CARPATHIANS MACROREGION}

The modern forests cover the features of continuous and discreteness in of environment the biosphere. These circumstances complicate the construction of models of types of the forest.

The main objective of forest policy and practice in European countries is sustainable forest management (SFM) as for using of forests and forest lands towards maintaining the capacity of biodiversity, productivity, sustainability and regeneration. The overall forest type is commonly understood as a category of forest defined by its composition and (or) conditions of the growth place so that the appropriate system of categories, each country came to this understanding and classification of forest types should determine and display the main natural and anthropogenic factors of differentiation of forest which can cause significant changes to the basic indicator of forest types.

In most states the basic principles of forestry planning take into account, first of all, the natural conditions: features of the geological structure and climate, climate change and local conditions of places of growth. On these principles the natural forest regionalization developed. Geological and climatic factors are considered in the relationship, which determines the existence of major geological and geomorphological structures. At the same time, the topography, climatic conditions and the composition of the rocks determine the nature of water and geochemical regime, the degree of supply moisture, the processes of physical and chemical leaching of rocks and soils, water transfer and accumulation of eroded substances, as well as the direction of redox processes. Based on the ecological mesh of forest types usually put a vertical row of tall vegetation stages. For every high-rise waist provides the relevant edaphic-gigrotopic coordination grid (or mutually subordinate lists), which contains a number of categories trophotopes, as well as a number of categories moisture conditions. 
The number of these categories may be different and they are given different meanings, reflecting not only the gradation of soil fertility, but also their capacity, acidity, nitrate availability. Specification of gigrotopes can contain 4 to 7 categories (subcategories) of moisture levels, or humid support, and interval moisture.

According to the degrees of altitude and vegetation types trophotopes submitted inherent potential types of natural forest plant communities. In the cells of this grid is placed the abbreviations of ecological forest types and names of associations of plant communities.

Key words: Alps, Carpathian Mountains, forests, structure, types, regionalization, Scientific Schools, geological substrate, geotopes, trophotopes, gigrotopes 